\title{
The Link between Brand Equity and Loyalty: Evidence from Traditional Medicine Market in Kumasi
} Metropolis, Ghana

\author{
Peter Kwasi Oppong, Maxwell A. Phiri \\ University of KwaZulu-Natal, Durban, South Africa \\ peteroppong72@gmail.com,phirim@ukzn.ac.za
}

\begin{abstract}
Building a vibrant brand in a highly competitive market is of strategic importance as it provides greater loyalty which generates large market share and decreases competitive pressure on a firm. However, there is a lack of empirical evidence on the role of brand equity in supporting the formation of loyalty in the traditional medicine market. The aim of this research is to investigate the impact of brand equity on loyalty in the traditional medicine market. Based on the dimensionality of Aaker`s brand equity framework, four research propositions were put forward and evaluated by using structural equation modelling. The study relied on a sample of 348 customers who buy herbal medicines from the traditional medicine market in Kumasi metropolis. The study established that perceived quality, brand association and awareness significantly contribute to enhance the value of the brands which in turn, creates loyalty in the traditional medicine market in the Kumasi Metropolis. Recognizing the strategic importance of loyalty to the success of a firm, traditional health practitioners should direct their efforts towards developing perceived quality, brand association and awareness to enhance the value of their brands to support loyalty in the Kumasi traditional medicine market.
\end{abstract}

Keywords: Brand awareness, Brand association, Perceived quality, Brand equity, Brand loyalty

\section{Introduction}

In recent years, herbal medicines play a critical role in primary health care worldwide, despite widespread use of conventional drugs in health care delivery. Herbal medicines are plant-derived products with curative or other health benefits comprising refined or crude substances obtained from plants (WHO, 1998). It has been highlighted that traditional or alternative medicine has been continued to be used for primary health care even in developed countries where allopathic medicines dominate the national health care system (WHO, 2000). A study showed that approximately 70 to $80 \%$ of the people who reside in advanced countries had used complementary or alternative medicine for different purposes (WHO, 2008). According to WHO (2011), nearly 70 to 95 percent of the population residing in the developed nations use herbal medicines to address their health care needs. In Ghana, approximately 80 percent of the populace depends on herbal medicines to meet their basic health care needs (UNDP, 2007). Herbal medicines produced in Ghana in the form of mixtures, capsules, pills, tablets, creams and ointments are distributed as over-the-counter (OTC) medicines (Essegbey, Awuni, Essegbey, Akuffobea \& Mica, 2014; WHO, 2011). Over the past decades, commercialization of herbal medicines in Ghana has been increasing steadily and the number of competing products distributed at the traditional herbal medicine market keeps on increasing every year.

As a result, traditional medicine companies are facing keen competition in the Kumasi traditional herbal medicine market (Essegbey et al., 2014). Building enduring brands with positive equity is recognised as a means of generating greater loyalty to gain predictable sales and higher profits in a highly competitive market (Aaker, 1992). Despite the strategic role of brand equity in supporting loyalty, an empirical study to confirm its importance in the traditional medicine market is lacking. In this regard, this paper seeks to establish the link between brand equity and loyalty in the traditional medicine market in the Kumasi Metropolis, Ghana. Specifically, this research is set out to assess the impact of perceived quality, brand association and awareness on brand equity and in turn, the influence of equity on loyalty in the traditional medicine market. Consequently, this paper will expand the limited literature on the importance of perceived quality, association, awareness and equity to loyalty in the traditional medicine industry. Furthermore, this study will enhance the practical knowledge and understanding of practitioners on the critical role of brand equity and its assets in supporting loyalty in the traditional medicine industry. 


\section{Literature Review}

Brand Loyalty: Aaker, (1991) defined brand loyalty as the attachment customers have to a brand. According to Oliver $(1999$, p. 34), brand loyalty is a "deeply held commitment to rebuy or re-patronize a preferred product or service consistently in the future, thereby causing repetitive same-brand or same brand-set purchasing, despite situational influences and marketing efforts having the potential to cause switching behaviour". Behavioural and attitudinal loyalty, have been identified as dimensions of brand loyalty in the marketing literature (Tepeci, 1999; Chaudhuri \& Holbrook, 2001). Behavioural or purchase brand loyalty relates to repeat patronage and the amount or proportion of category volume attributed to the brand (Keller, 2013), whereas attitudinal brand loyalty refers to the extent of dispositional commitment with respect to some exclusive value linked to the brand (Chaudhuri \& Holbrook, 2001). A study revealed that brand equity is positively influenced by both behavioural and attitudinal brand loyalty (ibid). Aaker, (1991) is of the view that a large loyal customer base is one of the key components of brand valuation as it provides sustainable cash flow to a firm. It has also been emphasized that brand loyalty leads to word-of-mouth advertising, higher relative brand pricing, greater market shares and time to react to competitive marketing pressures (Aaker, 1992; Chaudhuri \& Holbrook, 2001).

Conceptual Framework: The purpose of the conceptual framework is to explain graphically or narratively the main factors, concepts and variables in a study, and the presumed relationships among them (Miles \& Huberman, 1994). In this study, brand quality, association and awareness are recognised as independent variables, whilst equity is considered as mediating variable and brand loyalty is regarded as the dependent variable. The relationships among the variables are explained graphically in Figure I below. It can be observed in Figure I that brand quality, association and awareness directly influence brand equity and in turn, equity is positively related to loyalty. In this model, loyalty is operationalized as a "deeply held commitment to rebuy or re-patronize a preferred product or service consistently in the future, thereby causing repetitive same-brand or same brand-set purchasing, despite situational influences and marketing efforts having the potential to cause switching behaviour" (Oliver, 1999, p. 34).

Perceived quality is related to consumer's subjective evaluation of the overall excellence of a good (Zeithaml, 1988). Awareness relates to the health of the brand trace in the minds of customers and is composed of brand recognition and recall (Keller, 2013). Brand association relates to anything the consumer mentally links to the brand and consists of brand personality, perceived value and organizational association (Aaker, 1991; Buil, Martinez \& de Chernatony, 2013). Finally, brand equity is seen as the difference in consumer choice between a focal branded product and its generic version (Yoo, Donthu \& Lee, 2000).

Figure I: Conceptual Model

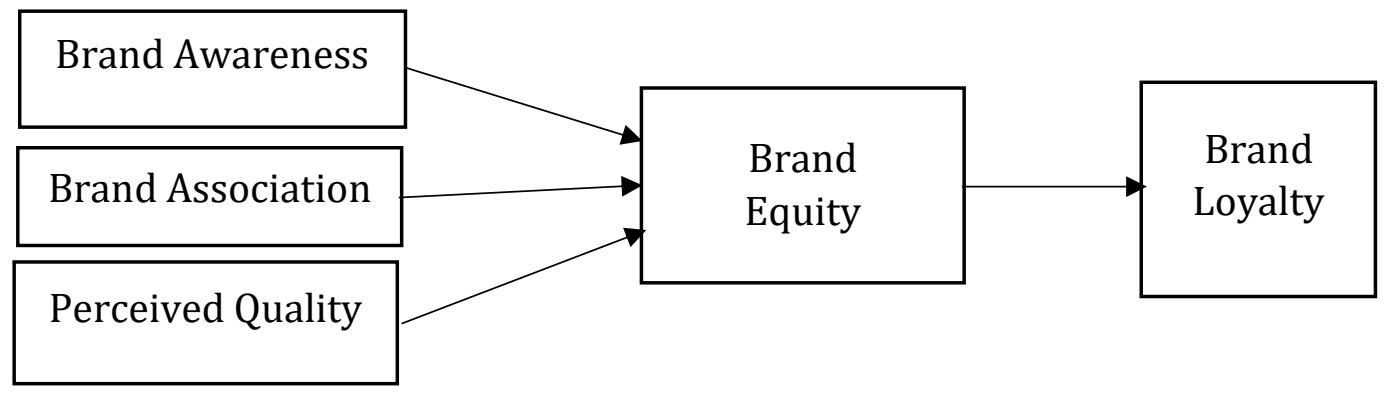

Source: Developed by the Researchers

Research Propositions: This study is set out to identify the link between brand equity and loyalty in the traditional medicine market. Based on the conceptual framework generated from the literature, the proposed relationship between brand equity and loyalty are discussed below.

Brand Awareness: Salience is recognized as a brand element that contributes to enhance the value of a brand (Aaker, 1996). Keller, (2013) described brand awareness as the health of the brand node in the minds 
of customers. The author further stated that brand salience consists of brand recall and recognition. Brand recognition shows the ability of consumers to confirm their previous exposures to the brand when the brand is used as a cue, whereas band recall indicates the ability of customers to retrieve the brand from their minds when the product class is given as cue (Hoeffler \& Keller, 2002). Aaker (1996), on the other hand, proposed brand identification, recall and top-of-mind awareness as the elements of brand salience. It has been noted that brand awareness has the potential to influence consumers' purchase intentions and loyalty (Aaker, 1991). Moreover, Keller (2013) contended that a high level of brand awareness can influence the consumer to include the brand in a set of alternatives to be purchased in the near future. The author further highlighted that strong brand awareness can affect consumer`s buying decision in terms of brands in the consideration set. Past studies revealed that brand awareness significantly contributes to influence the value of a brand (Asif, Abbas, Kashif, Hussain \& Hussain, 2015; Panchal, Khan, \& Ramesh, 2012). Hence, the following proposition is stated;

H1: There will be a significant and direct relationship between brand awareness and equity

Brand Association: Brand association is another dimension that creates value for a brand (Keller, 2013; Aaker, 1996). Brand association describes anything the customer mentally links to the brand (Aaker, 1991). Keller (1993) suggested that brand association is made up of attributes, benefits and attitudes in an increasing scope. However, perceived brand value, brand personality and organizational characteristics have also been identified in the literature as the elements of brand association (Aaker, 1996; Buil et al., 2013; Pappu, Quester \& Cooksey, 2005). Studies have also confirmed that perceived brand value, personality and organizational characteristics contribute to enrich the value of a brand (Buil et al., 2013; Pappu et al., 2005). Brand personality indicates a bundle of human characteristics that are attached to a brand (Aaker, 1997), whilst perceived value is concerned with consumers' subjective evaluation of the utility of an offering, in terms of, what is given out and received (Zeithaml, 1988).

The organizational association also is seen as organizational elements (people, values, and programs) that are linked to the brand (Aaker, 1996). It has been noted that brand associations provide a platform for brand differentiation, positioning, extension and as a basis for buying a particular brand (Aaker, 1991). Coupled with this, customers use brand association to process, organize and retrieve messages from the memory to assist them to make purchasing decisions (ibid). Chen, (2001) also highlighted that distinctive brand association strengthens the value of a brand and ultimately, creates a strong competitive advantage for a firm. Past studies also show that brand association directly influence brand equity (Tong \& Hawley, 2009; Sasmita \& Suki, 2015). As a result, the following hypothesis is formulated;

H2: There will be a significant and direct relationship between the brand association and equity

Perceived Quality: Aaker (1996) pointed out that brand quality is an important source of the value of a brand. Perceived quality relates to consumer's subjective evaluation of the overall excellence of a good (Zeithaml, 1988). According to Aaker (1992), perceived quality creates value for a firm by providing the basis for channel interest, differentiation, reason to buy the brand, higher brand prices, line extensions, and overall, increasing the profit margin. Perceived quality has also been recognized as an aspect of perceived value (Zeithaml, 1988), and hence, the superiority of a brand can influence a buyer to choose the brand relative to its competitors (Yoo et al., 2000).

Gil, Andres and Martinez (2007) emphasized that perceived brand quality can be improved by enhancing product quality. The authors also recommended that a company should convey the superiority of the brand via its marketing activities. Aaker, (1991) is of the view that consumers define product quality on the basis of its serviceability, performance, durability, reliability, product features, fit and finish and conformance to specification. However, it has also been proposed that safety, efficacy/efficiency, convenience, affordability, availability, side effects and packaging are quality dimensions in the drug industry (Dickov \& Igic, 2013; Osemene, Elujoba \& Ilori, 2011). Furthermore, earlier studies show that brand equity is positively influenced by a high level of perceived quality (Yoo et al., 2000; Buil et al., 2013). Consequently, the following proposition is stated;

H3: There will be a significant and direct relationship between perceived quality and equity 
Brand Equity: In today`s marketplace, the role of brand equity to the growth of businesses has attracted the attention of practitioners and academia. Keller, (2013) asserted that the most invaluable and enduring asset of a company is the brand name attached to its market offering. According to Aaker and Biel (1993), brand equity is the added value transferred to a product by branding. Thus, branding enhances the value of a product beyond its functional performance (Farquhar, 1989). Keller, (1993) also described brand equity with respect to marketing outcomes that are exclusively attributed to branding. The author further proposed customer-based brand equity (CBBE) and defined it as the differential effect that knowing the brand name has on consumer's reactions to the product and its marketing. Thus, a brand has positive (or negative) value when consumers react more positively (or negatively) to the product and the way it is marketed compared with a generic version of the product. In the author's view, the health of a brand and its ultimate worth to a company reside in the minds of customers. From the viewpoint of customer-based brand equity, brand knowledge is the key dimension of brand equity and is composed of brand image and awareness. The author also pointed out that customer-based brand equity depends on the extent of customers' awareness and familiarity with a brand and the strength, favorability, and uniqueness of the brand association.

On the other hand, Aaker (1991) proposed that brand equity comprises assets and liabilities that are linked with the brand name that increase or decrease the value of a product endowed to a firm and its clients. According to the author, brand association, loyalty, perceived quality, awareness and other proprietary brand assets like trademarks, channel relationship and patents are the main drivers of brand equity. However, Aaker (1996) concluded that perceived quality, association, loyalty and awareness are dimensions of customer-based brand equity, whilst the other brand elements are derived from market-based information rather than directly from customers. More importantly, CBBE is related to consumer perceptions of the brand and seen as the relationship they have with the brand (Kapferer, 2008; Christodoulides \& de Chernatony, 2010). Keller (2013) reported that powerful brands with high equity provide several marketing benefits to a firm which include: greater loyalty, more inelastic to customers' response to price increases, trade leverage, licensing and brand extensions opportunities. Moreover, Aaker (1991) pointed out that brand equity creates value to the customers by assisting in the interpretation, processing and storing product information as well as purchasing decisions. It has also been emphasized that a high level of brand equity significantly influences loyalty (Lassar, Mittal \& Sharma, 1995; Taylor, Celuch \& Godwin, 2004). Hence, the following proposition is stated;

H4: There will be a significant and direct relationship between brand equity and loyalty

\section{Research Methodology}

The plan of study used to test the propositions posited in this paper is discussed below. In the current study, herbal medicines manufactured by Ghanaian firms and were distributed in registered herbal stores in the Kumasi Metropolis were targeted. These plant medicines have been licenced by the Food and Drugs Authority which is mandated by law to regulate the production and distribution of medicines in the country. Even though, pharmacies and licensed chemists stores are mandated to distribute both herbal and conventional drugs, recruiting participants in these stores was impracticable. As a result, registered herbal stores were selected because they are authorised by law to sell only plant medicinal products. Furthermore, Kumasi metropolis was selected as a study site because it is the second largest commercial city in Ghana and is endowed with a wide variety of medicinal plants (GSS, 2014). These have led to the localization of traditional medicine firms within the metropolis.

Test Instruments Development: Closed-ended questionnaires with a five-point Likert scale anchored on strongly disagree (1) to strongly agree (5) were employed to capture the perceptions of customers' awareness, association, loyalty and brand equity of herbal medicines. Survey questionnaires were utilized because of data collected permit better mathematical calculations and interpretations (Mackenzie \& Knipe, 2006; Creswell, 2014). In addition, the customers were busy shopping and as a result, closed-ended questionnaires provided them with more convenience to respond quickly. The test instruments for measuring the research constructs were guided by previous test instruments. The test instruments for measuring brand awareness were obtained from Yoo et al. (2000), Tong and Hawley (2009) and Gil et al. (2007) and test items of perceived quality were developed by Yoo et al. (2000) and Gil et al. (2007). 
Moreover, the test instruments of loyalty were borrowed from Tong and Hawley (2009), Aaker (1996), Yoo et al. (2000) and Gil et al. (2007). Finally, test items for measuring association were designed by Aaker (1996) and Netemeyer, Krishna, Pullig, Wang, Yagci, Dean, Ricks \& Wirth (2004), whilst test instruments of brand equity were developed by Yoo et al. (2000).

Sample and Data Collection Methods: The study population was made up of 80 licensed herbal shops, of which 20 provide wholesale services, whilst 60 offer only retail services in Kumasi metropolis. These data were obtained from the Traditional Medicine Practice Council (TMPC) in Kumasi. To increase the representativeness of both wholesale and retail shops in the research, a stratified sampling strategy was employed to select a sample of herbal shops operating in the Kumasi metropolis (Saunders, Lewis \& Thornhill, 2007). Based on the Krejcie and Morgan, (1970) framework of sample size estimation, a sample of 19 and 52 was selected from the 20 wholesale and 60 retail herbal shops respectively. Moreover, from the 2017 data of the 80 herbal retail outlets, 3710 customers aged 18 and above usually buy herbal medicines on a daily basis in the Metropolis. Following the recommendation of Krejcie and Morgan model, a total of 348 customers were recruited to participate in this research. Using systematic sampling strategy, the questionnaires were administered to the customers by contacting them face-to-face at the entrance of the stores. Thus, the first customer who entered the store was randomly picked and afterwards, one in every eleven customers was requested to complete the questionnaire until the total sample was obtained. Systematic sampling was used because it provides an opportunity to recruit research participants without knowing their characteristics from the sample frame (Malhotra \& Birks, 2007).

\section{Data Analysis and Results}

Three hundred and sixteen (316) questionnaires were received, but 307 were usable because nine (9) were incomplete. Out of the total number of 304 (three were missing values), 68.4 percent (208) were male whilst 31.6 percent (96) were female, 40.7 percent (124) were between 18 and 25 years, 39.2 percent (120) had secondary education, 36.7percent (110) were traders and finally, 61.2 percent (127) earned a daily income above USD $\$ 2$. This indicates that a large proportion of the customers was young traders, moderate to highincome earners and had secondary education.

Reliability and Validity of Test Instruments: In line with previous research (Tong \& Hawley, 2009; Gil et al., 2007), the test instruments were validated by using exploratory factor analysis, Cronbach`s alpha coefficient, and confirmatory factor analysis.

Internal Consistency Reliability: Cronbach`s alpha statistics was employed to investigate the internal consistency of the indicator items that emerged from the exploratory factor analysis. The results showed that Cronbach`s alpha of test items of brand association, awareness, loyalty, perceived quality and equity were higher than the recommended value of .70, ranging from .773 to .894. This shows good internal consistency reliability (Hair, Black, Babin \& Anderson, 2010; Tavakol \& Dennick, 2011), as shown in Table I below. Consequently, the reliability estimates of the test items of all the latent constructs were satisfactory and 20 test items were used for measuring the five latent constructs in the structural equation model.

Exploratory Factor Analysis: Exploratory factor analysis (EFA) was carried out to investigate the extent to which the individual test item loads on its respective latent constructs as purported, to produce brand awareness, loyalty, perceived quality, association and equity. Table I below exhibits the findings of the exploratory factor analysis. Twenty-six test items were subjected to EFA in this study. In order to check the adequacy of the sample size for successful EFA, Kaiser-Meyer-Olkin (KMO) Measure of Sampling Adequacy was undertaken. The results showed a coefficient of .926 which exceeded the acceptable threshold of .60, demonstrating that the sample size of the study is admissible (Pallant, 2013). Furthermore, the Bartlett's Test of Sphericity $\left(\mathrm{X}^{2}=4479.355, \mathrm{DF}=325, \mathrm{p}=.000\right)$ was statistically significant at $\mathrm{p}<.001$, which demonstrates that the EFA is acceptable (Hair et al., 2010).

The EFA via maximum likelihood factoring with Promax method yielded five distinct latent constructs. In order to obtain significant factor loadings, test items that loaded less than 0.30 were discarded (Floyd \& Widaman, 1995) and overall, 20 test items were retained with loadings ranging between .350 and 1.05. 
Moreover, all five constructs have eigenvalues greater than one. All the five constructs explained $63.40 \%$ of the total variance, suggesting that more than half of the variance in the explored phenomena is explained by these constructs. The first factor is perceived quality, the second is awareness, third is equity, the fourth is an association, and the fifth is loyalty. This outcome confirms that CBBE is a multidimensional construct consistent with Aaker`s (1996) conceptualization. To confirm discriminant validity, the loadings of each test instruments on their own constructs exceeded the cross-loadings on any other constructs (Hair et al., 2010).

Table 1: Results of Exploratory Factor Analysis

\begin{tabular}{|c|c|c|c|c|c|c|}
\hline \multirow{2}{*}{\multicolumn{2}{|c|}{ Test Items }} & \multicolumn{4}{|c|}{ Factors } & \multirow[b]{2}{*}{5} \\
\hline & & 1 & 2 & 3 & 4 & \\
\hline Q1 & $\mathrm{X}$ is safe for use & .697 & & & & \\
\hline Q2 & $\mathrm{X}$ functions perfectly & .939 & & & & \\
\hline Q3 & $\mathrm{X}$ is a very reliable product & .851 & & & & \\
\hline Q4 & The quality of $\mathrm{X}$ is very high & .761 & & & & \\
\hline Q5 & $\begin{array}{l}\text { I can always trust this brand if I want a herbal drug of } \\
\text { high quality }\end{array}$ & .909 & & & & \\
\hline AW1 & I know what X looks like & & .622 & & & \\
\hline AW2 & I can easily recognise $\mathrm{X}$ among other competing brands & & .683 & & & \\
\hline AW3 & I am familiar with $X$ & & .634 & & & \\
\hline AW7 & I am aware of X & & .650 & & & \\
\hline EQ1 & $\begin{array}{l}\text { It makes sense to buy X instead of any other brand, } \\
\text { even if they are of the same price or quality }\end{array}$ & & & .558 & & \\
\hline EQ2 & $\begin{array}{l}\text { Even if another brand has the same features as X, I } \\
\text { would prefer to buy X }\end{array}$ & & & 1.05 & & \\
\hline EQ3 & If there is another brand as good as $\mathrm{X}$, I prefer to buy $\mathrm{X}$ & & & .759 & & \\
\hline EQ4 & $\begin{array}{l}\text { If another brand is not different from } \mathrm{X} \text { in any way, it } \\
\text { seems smarter to purchase } \mathrm{X}\end{array}$ & & & .574 & & \\
\hline AS1 & X offers good value for money & & & & .795 & \\
\hline AS2 & $\begin{array}{l}\mathrm{X} \text { gives me a reason to buy over other competing } \\
\text { brands }\end{array}$ & & & & .748 & \\
\hline AS3 & $\begin{array}{l}\text { When I consider what I would pay for X, I would get } \\
\text { much more than my money's value }\end{array}$ & & & & .452 & \\
\hline AS10 & $\mathrm{X}$ is in the upper-class & & & & .513 & \\
\hline L01 & $\begin{array}{l}\text { When buying herbal medicines, } \mathrm{X} \text { would be my first } \\
\text { choice }\end{array}$ & & & & & .350 \\
\hline L02 & I would not buy other brands if $\mathrm{X}$ is available at store & & & & & .573 \\
\hline L04 & $\begin{array}{l}\text { I am still willing to buy } \mathrm{X} \text { even if its price is a little } \\
\text { higher than that of competing brands }\end{array}$ & & & & & .443 \\
\hline \multicolumn{2}{|c|}{ Cronbach Alpha } & .894 & .786 & .867 & .773 & .773 \\
\hline \multicolumn{2}{|c|}{ Eigenvalues } & 10.76 & 1.97 & 1.33 & 1.28 & 1.12 \\
\hline \multirow{2}{*}{\multicolumn{2}{|c|}{$\begin{array}{l}\text { Percentage of Variance Explained } \\
\text { Percentage of Total Variance Explained }=63.40\end{array}$}} & 41.40 & 7.61 & 5.11 & 4.94 & 4.32 \\
\hline & & & & & & \\
\hline \multicolumn{7}{|c|}{ KMO $=0.926 ;$ Bartlett's Test of Sphericity: $X^{2}=4479.355 ; D F=325 ; p=0.000$} \\
\hline
\end{tabular}

Source: Field Survey

Structural Equation Model: To analyse the research propositions stated in this paper, structural equation modelling was conducted. As Byrne (2016) suggested, the measurement model was carried out via confirmatory factor analysis (CFA), followed by the path or structural model.

Measurement Model: A statistical software known as SPSS Amos 22 using the maximum likelihood method was employed to carry out the CFA to further confirm the results generated from the EFA and also to evaluate the construct validity. To attain good construct validity and a plausible model, standardised residual estimates of pairs of indicators exceeding 2.58 were discarded because they indicate a high degree of miscalculation in the model measurement (Byrne, 2016). In addition, to achieve convergent validity, 
individual test items with standardised loadings less than .50 were also discarded (Hair et al., 2010). Hence, four test items were deleted from this analysis. The findings of the CFA in Table II demonstrate that 16 test items converged on their respective variables. Moreover, all the individual standardized loadings proved to be statistically significant which ranged from .634 to .891 , providing a test for construct validity (Hair et al., 2010). Although, the Chi-square statistics $\left(X^{2}=217.229, D F=94, p<.001\right)$ failed to confirm the model, the other indexes produced acceptable estimates in this analysis. The Normed Chi-square statistic (CMIN/DF) was 2.311 which is less than three (Kline, 2005). The Standardised Root Mean Square Residual (SRMR), Root Mean Residual (RMR) and Root Mean Square Error of Approximation (RMSEA) were .044, .036 and .065 which are much lower than the proposed cut-off of .08 respectively (Hu \& Bentler, 1999).

Lastly, the Tucker-Lewis Index (TLI), Incremental Fit Index (IFI), Comparative Fit Index (CFI), Normed Fit Index (NFI) and Goodness-of-Fit Index (GFI) were .934, .949, .948, .913 and .923 respectively. These estimates demonstrate that the model fitted well with the data and therefore provided an admissible solution for the measurement model (Hu \& Bentler, 1999; Hair et al., 2010). In addition, Table II below exhibits Average Variance Extracted (AVE) and Composite Reliability (CR) of the variables of the measurement model. First, CR was computed to examine the internal consistency of the individual variables in the measurement model. Even though CR is analogous to Cronbach`s alpha, the former is commonly used in conjunction with structural equation modelling and also provides a slightly better assessment of internal consistency reliability (Washburn \& Plank, 2002; Hair et al., 2010).

The results of the CR revealed that all the variables had estimates above .70, which ranged from .759 to .861 , signifying satisfactory levels of internal consistency (Hair et al., 2010). Furthermore, AVE was used to assess the convergent validity of the constructs in the CFA. The findings of the AVE demonstrate that the variables had estimates above the threshold of .50, confirming convergent validity (Kline, 2005; Hair et al., 2010). Moreover, Table III reveals the findings of discriminant validity statistics of the measurement model. The findings show that the square root of the values of AVE was above the squared correlation estimates between a variable and any other variables, which demonstrate independence between the variables (Hair et al., 2010). These findings indicate that awareness, quality, association, loyalty and equity are valid and reliable variables in the measurement model.

Table 2: Results of Confirmatory Factor Analysis

\begin{tabular}{|c|c|c|c|c|}
\hline Constructs and Test Items & CR & AVE & Standardized Loadings & t-value \\
\hline Brand Awareness & .761 & .515 & & \\
\hline AWI & & & .719 & $-\mathrm{a}$ \\
\hline AW2 & & & .723 & 10.078 \\
\hline AW7 & & & .711 & 9.993 \\
\hline Brand Association & .759 & .515 & & \\
\hline AS1 & & & .661 & $-\mathrm{a}$ \\
\hline AS2 & & & .832 & 10.657 \\
\hline AS10 & & & .645 & 9.308 \\
\hline Perceived Quality & .861 & .539 & & \\
\hline Q1 & & & .739 & 13.190 \\
\hline Q2 & & & .778 & 14.000 \\
\hline Q3 & & & .825 & 14.948 \\
\hline Q4 & & & .776 & $-\mathrm{a}$ \\
\hline Brand Loyalty & .777 & .608 & & \\
\hline L01 & & & .786 & 13.581 \\
\hline LO2 & & & .634 & 10.785 \\
\hline L04 & & & .774 & $-\mathrm{a}$ \\
\hline Brand Equity & .856 & 666 & & \\
\hline EQ2 & & & .836 & $-\mathrm{a}$ \\
\hline EQ3 & & & .891 & 17.371 \\
\hline EQ4 & & & .710 & 13.465 \\
\hline
\end{tabular}


Notes: $\mathbf{X}=$ Focal brand; $\mathbf{C R}=$ Composite Reliability; $\mathbf{A V E}=$ Average Variance Extracted; $\mathbf{a}=$ path parameter was set to 1 , therefore no $t$-values were estimated; All loadings are significant at 0.001 level.

Table 3: Discriminant Validity Analysis

\begin{tabular}{llllll}
\hline Constructs & $\begin{array}{l}\text { Brand } \\
\text { Awareness }\end{array}$ & $\begin{array}{l}\text { Brand } \\
\text { Association }\end{array}$ & Brand Loyalty & $\begin{array}{l}\text { Perceived } \\
\text { Quality }\end{array}$ & $\begin{array}{l}\text { Brand } \\
\text { Equity }\end{array}$ \\
\hline Brand Awareness & $.718^{* *}$ & & & & \\
Brand Association & .217 & $.718^{* *}$ & & & \\
Brand Loyalty & .319 & .504 & $.734^{* *}$ & $.780^{* *}$ & \\
Perceived Quality & .319 & .442 & .726 & .452 & $.816^{* *}$ \\
Brand Equity & .309 & .352 & .533 & \\
\hline
\end{tabular}

Notes: $^{* *}=$ Square Root of AVEs; Off-diagonal estimates represent the Squared Inter-Construct Correlations

Structural Model: The path model was conducted to examine the statistical significance of the hypotheses in this research. Brand association, awareness and perceived quality are specified as independent variables, whilst equity is a mediating variable and loyalty is recognized as the endogenous construct. While the Chisquare statistics $\left(\mathrm{X}^{2}=265.553, \mathrm{DF}=96, \mathrm{p}=.000\right)$ failed to confirm the path model, other fit indexes supported the structural model; $\mathrm{X}^{2} / \mathrm{DF}=2.766 ; \mathrm{RMR}=.043 ; \mathrm{GFI}=.906 ; \mathrm{IFI}=.930 ; \mathrm{TLI}=.911 ; \mathrm{CFI}=.929 ; \mathrm{RMSEA}=.076$; SRMR $=.050$. The findings of the structural model in Table III show that brand salience $(B=.199, t=3.060)$ is statistically significant and directly influences equity at $\mathrm{p}<.01$ level. Furthermore, the findings of the structural model demonstrate that association $(B=.280, t=3.747)$ and perceived quality $(B=.550, t=6.436)$ are statistically significant and directly influences equity at $p<.001$. In turn, equity is $(\beta=.918, t=11.134)$ statistically significant and directly related to loyalty at $\mathrm{p}<.001$ level.

Finally, the test results further show that perceived quality $(ß=.550)$ has a greater impact on brand equity than brand awareness and association. These findings confirm $\mathrm{H} 1, \mathrm{H} 2, \mathrm{H} 3$ and $\mathrm{H} 4$ as proposed in the study. In the path analysis, no direct relationship between perceived quality, association, awareness and loyalty was stated, yet as conceptualized in this paper, perceived quality, association and awareness indirectly influence loyalty via the impact of equity. To determine the indirect effect of perceived quality, association and awareness on loyalty, bootstrap was conducted through re-sampling of 1000 at a biased-corrected confidence level of $95 \%$. The findings reveal that the indirect effect of brand awareness $(\beta=.182, p=.014)$, perceived quality $(\beta=.505, p=.002)$ and association $(\beta=.257, p=.002)$ on brand loyalty is statistically significant at $p$ $<.001$ two-tailed level. These findings further show that perceived quality, association and awareness indirectly influence loyalty through the mediated effect of brand equity.

Table 4: Results of Hypotheses Testing

\begin{tabular}{llcccc}
\hline Hypotheses & Structural relations & $\begin{array}{c}\text { Standardized } \\
\text { Estimates (B) }\end{array}$ & t-value & p-value & Outcome \\
\hline H1 & Brand equity <--- Brand awareness & .199 & 3.060 & .002 & Accepted \\
H2 & Brand equity <--- Brand association & .280 & 3.747 & .000 & Accepted \\
H3 & Brand equity <----Perceived quality & .550 & 6.436 & .000 & Accepted \\
H4 & Brand loyalty <---Brand equity & .918 & 11.134 & 0.000 & Accepted \\
\hline
\end{tabular}

Discussion: The purpose of this research was to investigate the link between brand equity and loyalty in the traditional health market in Kumasi metropolis. Specifically, the study was set out to assess the influence of perceived quality, association and awareness on equity and in turn, the impact of equity on loyalty in the traditional medicine industry. The findings of the research reveal that awareness significantly strengthens brand equity in the traditional medicine market. This result concurs with earlier authors (Asif et al., 2015; Panchal et al., 2012), who suggested that high brand awareness contributes to enhance equity. However, this result is contrary to earlier research carried out by Yoo et al. (2000) and Gil et al. (2007), which confirmed that brand salience did not have a direct effect on equity. Moreover, the study found that brand association positively influences brand equity in the traditional herbal medicine market. This is in line with the findings of previous research (Tong \& Hawley, 2009), which established that association strengthens brand equity in the sportswear industry. Furthermore, the results reveal that equity is positively affected by perceived quality in the traditional medicine market. 
This outcome concurs with the results of earlier authors (Yoo et al., 2000; Buil et al., 2013), who found that high perceived quality significantly enhances the value of a brand. In addition, the findings of the research show that perceived quality is the primary source of value for brands in the Kumasi traditional medicine market. This result is consistent with the previous study (Piaralal \& Mei, 2015), which showed that perceived quality had a greater influence on brand equity than any other brand asset in the private healthcare facilities in Klang Valley, Malaysia. The study also revealed that loyalty is positively affected by brand equity in the traditional medicine market in Kumasi metropolis. This outcome concurs with the findings of previous research (Taylor et al., 2004), which suggests that attitudinal and behavioural forms of loyalty are consistently influenced by a high level of equity. This outcome also concurs with existing literature (Aaker, 1991; Keller, 2013) which indicates that loyalty is one of the consequences of equity that provides valuable business results to a firm. Finally, consistent with an earlier study (Alverdi, 2017), this study confirms that brand awareness, association and perceived quality significantly enhance loyalty via the indirect impact of equity in the traditional medicine industry.

\section{Conclusion and Recommendations}

Recommendations: In accordance with the findings of this research, the following recommendations are made; the research found that brand awareness creates value for brands in the traditional medicine market in the Kumasi metropolis. As a result, traditional medicine practitioners should focus on building consumers' awareness of their brands to enhance their value in the market. Coupled with this, traditional medicine firms should develop awareness messages that can be differentiated and recalled by the target market in the cluttered media communication environment. Additionally, the study revealed that brand association increases the value of the brands in the traditional medicine market in the Kumasi metropolis. Hence, traditional medicine firms should develop valuable associations of their brands to enhance equity in the Kumasi traditional medicine market. Enhancing the perceived value of their brands can also enrich the associations consumers attached to these brands.

The study also points out that brand equity is dominantly influenced by perceived quality in the traditional medicine market in the metropolis. In order to enhance consumers 'perceptions of the quality of herbal medicines, traditional medicine firms should allocate more resources to develop superior products consistently, especially in relation to their competitors' products. The research also established that brand quality, awareness and association significantly enhance loyalty via the indirect role of equity in the Kumasi traditional medicine market. As a result, traditional medicine companies should consider consumer`s awareness, associations that are linked to their brands and perceptions of brand quality in their loyaltybuilding activities which if they are increased, can indirectly contribute to enhancing loyalty in the traditional medicine market. Lastly, traditional medicine companies should constantly track and measure customers` perceptions of the value of their brands in order to increase and maintain loyalty in the traditional medicine market in Kumasi metropolis.

Conclusion: This paper was set out to empirically assess the link between brand equity and loyalty in the traditional medicine industry in Kumasi metropolis. Essentially, the research aimed to investigate the influence of perceived quality, brand association and awareness on equity and in turn, the impact of equity on loyalty in the Kumasi traditional health market. The study found that brand quality, association and awareness are the core elements of value for brands in the traditional medicine market in Kumasi metropolis. More importantly, perceived quality was found to be the most important brand asset compared to brand awareness and association in the traditional health market. The study also established that brand equity acts as a mediator in the path between perceived quality, association, awareness and loyalty in the traditional medicine market in Kumasi metropolis, Ghana. The study concludes that, although loyalty is regarded as one of the brand assets, it is one of the ways that brand equity and the other dimensions interact to create sustainable value for a firm.

Limitations and Future Research: Although the research was based on sound methodology and literature, the study had some limitations that require future research to further enhance the generalization of the results. While, herbal medicines are bought online and in the in-store retail environment, this study focused on in-store retail outlets in the Kumasi metropolis. Future research should include customers who buy herbal 
medicines from the online retail environment to enrich the generalization of the findings of this research. In addition, the sample of the study was drawn from only Kumasi Metropolis in Ghana. Future research should consider a larger sample drawn from other parts of the country in order to improve the generalizability of the study.

\section{References}

Aaker, D. A. (1991). Managing Brand Equity: Capitalizing on the Value of Brand Name. New York: The Free Press.

Aaker, D. A. (1992). The Value of Brand Equity. Journal of Business Strategy, 13(4), 27-32.

Aaker, D. A. (1996). Measuring Brand Equity across Products and Markets. California Management Review, 38(3), 102-120.

Aaker, J. L. (1997). Dimensions of Brand Personality. Journal of Marketing Research, 34(3), 347-357.

Aaker, D. A. \& Biel, A. L. (1993). Brand Equity and Advertising: Advertising`s Role in Building Strong Brands. New York: Psychology Press.

Alverdi, M. (2017). Effects of Brand Factors on Customer Loyalty with the Mediating Role of Brand Equity. International Academic Journal of Accounting and Financial Management, 4(2), 36-46.

Asif, M., Abbas, K., Kashif, M., Hussain, S. \& Hussain, I. (2015). Impact of Brand Awareness and Loyalty on Brand Equity. Journal of Marketing \& Consumer Research, 12, 67-72.

Buil, I., Martinez, E. \& de Chernatony, L. (2013). The Influence of Brand Equity on Consumer Responses. Journal of Consumer Marketing, 30(1), 62-74.

Byrne, B. M. (2016). Structural Equation Modelling with AMOS: Basic Concepts, Applications and Programming, ( $3^{\text {rd }}$ ed.), New York, NY 10017: Taylor \& Francis Group.

Chaudhuri, A. \& Holbrook, M. B. (2001). The Chain of Effects from Brand Trust and Brand Affect to Brand Performance: The Role of Brand Loyalty. Journal of Marketing, 62(2), 81-93.

Chen, A. C. H. (2001). Using Free Association to Examine the Relationship between the Characteristics of Brand Association and Brand Equity. Journal of Product and Brand Management, 10(7), 439-457.

Christodoulides, G. \& de Chernatony, L. (2010). Customer-Based Brand Equity Conceptualization and Measurement: A Literature Review. International Journal of Research in Marketing, 52(1), 43-66.

Creswell, J. W. (2014). Research Design: Qualitative, Quantitative, and Mixed Methods Approaches, (4th ed.), California: SAGE Publications Inc.

Dickov, V. \& Igić, S. (2013). The Aspect of Brands and Marketing Development in Pharmaceutical Industry in Transition Countries. International Journal of Operations \& Logistics Management, 2(4), 49-57.

Essegbey, G. O., Awuni, S., Essegbey, I. T., Akuffobea, M. \& Mica, B. (2014). Country Study on Innovations, Intellectual Property and Informal Economy: Traditional Medicines in Ghana, (13 ${ }^{\text {th }}$ ed.), World International Property Organization, Geneva.

Farquhar, P. H. (1989). Managing Brand Equity. Marketing Research, 24-33.

Floyd, F. J. \& Widaman, K. F. (1995). Factor Analysis in the Development and Refinement of Clinical Assessment Instrument. Psychological Assessment, 7(3), 286-299.

Gil, R. B., Andres, E. F. \& Martinez, E. S. (2007). Family as Source of Customer-Based Brand Equity. Journal of Product \& Brand Management, 16(3), 188-199.

GSS. (2014). 2010 Population and Housing Census: District Analytical Report of Kumasi Metropolitan Assembly.

Hair, J. H. J. R., Black, W. C., Babin, B. J. \& Anderson, R. E. (2010). Multivariate Data Analysis: A Global Perspective, ( $7^{\text {th }}$ ed.), New York: Pearson Prentice Hall.

Hoeffler, S. \& Keller, K. L. (2002). Building Brand Equity through Corporate Societal Marketing. Journal of Public Policy and Marketing, 21(1), 78-89.

Hu, L. \& Bentler, P. M. (1999). Cut-off Criteria for Fit Indexes in Covariance Structure Analysis: Conventional Criteria versus New Alternatives. Structural Equation Modelling Multidisciplinary Journal, 6(1), 1- 55.

Keller, K. L. (1993). Conceptualization, Measuring, and Managing Customer-Based Brand Equity. Journal of Marketing, 57(1), 1-22.

Keller, K. L. (2013). Strategic Brand Management: Building Measuring and Managing Brand Equity, (4th ed.), England: Pearson Education Ltd.

Kapferer, J. N. (2008). The New Strategic Brand Management: Creating and Sustaining Brand Equity ～Long Term, ( $4^{\text {th }}$ ed.), London: Kogan Page Limited 
Kline, R. B. (2005). Principles and Practice of Structural Equation Modelling, (2nd ed.), New York, NY 10012: Guilford Press.

Krejcie, R. V. \& Morgan, D. W. (1970). Determining Sample Size for Research Activities. Educational \& Psychological Measurement, 30, 607-610.

Lassar, M., Mittal, B. \& Sharma, A. (1995). Measuring Customer-Based Brand Equity. Journal of Consumer Marketing, 12(4), 11-19.

Netemeyer, R. G., Krishna, B., Pullig, C., Wang, G., Yagci, M., Dean, D., Ricks, J. \& Wirth, F. (2004). Developing and Validating Measures of Facets of Customer-based Brand Equity. Journal of Business Research, 57, 209-224.

Mackenzie, N. \& Knipe, S. (2006). Research Dilemmas: Paradigms, Methods and Methodology. Issues in Educational Research, 16, 193-205.

Malhotra, N. K. \& Birks, D. F. (2007). Marketing Research: An Applied Approach, (3 ${ }^{\text {rd }}$ ed.), England: Pearson Education Limited.

Miles, M. B. \& Huberman, A. M. (1994). Qualitative Data Analysis: An Expanded Sourcebook, (2 ${ }^{\text {nd }}$ ed.), California: SAGE Publication, Inc.

Oliver, R. L. (1999). Whence Consumer Loyalty? Journal of Marketing, 63, 33-44.

Osemene, K. P., Elujoba, A. A. \& Ilori, M. O. (2011). A Comparative Assessment of Herbal and Orthodox Medicines in Nigeria. Research Journal of Medical Sciences, 5(5), 280-285.

Pallant, J. (2013). SPSS Survival Manual: A Step by Step Guide to Data Analysis using IBM SPSS, (5 $5^{\text {th }}$ Ed.), New York: McGraw-Hill Education.

Panchal, S. K., Khan, B. M. \& Ramesh, S. (2012). Importance of Brand Loyalty, Brand Awareness, and Perceived Quality Parameters in Building Brand Equity in Indian Pharmaceutical Industry. Journal of Medical Marketing, 12(2), 81-92.

Pappu, R., Quester, P. G. \& Cooksey, R. W. (2005). Customer-Based Brand Equity: Improving the Measurement-Empirical Evidence. Journal of Product \& Brand Management, 14(4), 143-154.

Piaralal, S. \& Mei, T. M. (2015). Determinants of Brand Equity in Private Healthcare Facilities in Klang Valley, Malaysia. American Journal of Economics, 5(2), 177-182.

Sasmita, J. \& Suki, N. M. (2015). Young Consumers` Insights on Brand Equity: Effects of Brand Association, Brand Loyalty, Brand Awareness, and Brand Image. International Journal of Retail \& Distribution Management, 43(3), 276-292.

Saunders, M., Lewis, P. \& Thornhill, A. (2007). Research Methods for Business Students, (4th ed.), England: Pearson Education Limited.

Taylor, S. A., Celuch, K. \& Godwin, S. (2004). The Importance of Brand Equity to Customer Loyalty. Journal of Product \& Brand Management, 13(4), 217-227.

Tavakol, M. \& Dennick, R. (2011). Making Sense of Cronbach`s Alpha. International Journal of Medical Education, 2, 53-55.

Tepeci, M. (1999). Increasing Brand Loyalty in the Hospitality Industry. International Journal of Contemporary Hospitality Management, 11(5), 223-229.

Tong, X. \& Hawley, J. M. (2009). Measuring Customer-Based Brand Equity: Empirical Evidence from Sportswear Market in China. Journal of Product \& Brand Management, 18(4), 262-271.

UNDP. (2007). The Ghana Human Development Report: Towards a More Inclusive Society, Ghana.

Washburn, J. H. \& Plank, R. E. (2002). Measuring Brand Equity: An Evaluation of Customer-Based Brand Equity Scale. Journal of Marketing Theory and Practice, 10(1), 46-62.

WHO. (2000). General Guidelines for Methodologies on Research and Evaluation of Traditional Medicine, Geneva.

WHO. (1998). Guidelines for Appropriate Use of Herbal Medicines. WHO Regional Publication, Western Pacific Series, No. 23, Manila.

WHO. (2011). Traditional Medicines, Global Situation, Issues and Challenges.

WHO. (2008). Traditional Medicine. Fact Sheet No. 134.

Yoo, B., Donthu, N. \& Lee, S. (2000). An Examination of Selected Marketing Mix Elements and Brand Equity. Journal of the Academy of Marketing Science, 28(2), 195-211.

Zeithaml, V. A. (1988). Consumer Perceptions of Price, Quality, and Value: A Means-End Model and Synthesis of Evidence. Journal of Marketing, 52, 2-22. 